\title{
ANALISIS LEAN MANUFACTURING UNTUK MINIMASI WASTE PADA PROSES DOOR PU
}

\author{
Ratna Novitasari ${ }^{\star}$, Irwan Iftadi \\ Program Studi Teknik Industri, Fakultas Teknik, Universitas Sebelas Maret \\ Email: ratnanvtsr@student.uns.ac.id; iftadi@gmail.com
}

Artikel masuk : 04-02-2020

Artikel direvisi : 19-04-2020

Artikel diterima : 16-06-2020

${ }^{*}$ Penulis Korespondensi

\begin{abstract}
Abstrak - PT XYZ merupakan sebuah perusahaan manufaktur yang bergerak dalam penyedia alatalat rumah tangga, salah satunya adalah kulkas. Pada proses produksi Door PU di divisi refrigerator terdapat permasalahan pencapaian output produksi yang lebih rendah dibandingkan dengan target produksi pada Door PU produk kulkas 1 pintu serta freezer. Penelitian ini membahas mengenai analisis lean manufacturing pada proses identifikasi dan minimasi waste yang ada pada proses Door PU di divisi refrigerator PT XYZ. Penelitian dilakukan dengan 4 tahapan. Tahap pertama adalah pembuatan Value Stream Mapping (VSM) untuk menunjukan keseluruhan proses produksi Door PU. Tahap kedua dilakukan identifikasi waste dan break down tahapan proses produksi dalam bentuk process activity mapping. Tahap ketiga adalah proses identifikasi akar permasalahan dari waste yang telah diketahui dengan menggunakan root cause analysis - 5 Why's. Berdasarkan penelitian yang dilakukan, didapatkan hasil waste berupa waiting dan defect, dengan nilai operasi value added sebesar $11,54 \%$, non value added $7,69 \%$, dan operasi necessary non value added sebesar $76,43 \%$. Rekomendasi perbaikan mampu mengurangi total aktivitas proses dari 26 menjadi 24 serta peningkatan nilai PCE menjadi $31,45 \%$.
\end{abstract}

Kata Kunci: Lean Manufacturing; Root Cause Analysis; Value Stream Mapping; Waste

\begin{abstract}
PT $X Y Z$ is a manufacturing company engaged in the supply of household appliances, one of which is a refrigerator. In the Door PU production process in the refrigerator division, there is a problem of achieving lower production output compared to the production target of the Door PU 1 door refrigerator and freezer products. This study discusses the analysis of lean manufacturing is the process of identifying and minimizing waste that exists in the Door PU process in the refrigerator division of PT XYZ. The study was conducted in 4 stages. The first stage is the creation of Value Stream Mapping (VSM) to show the entire Door PU production process. The second stage is to identify waste and break down steps of the production process in the form of process activity mapping. The third stage is the process of identifying root causes of known waste using root cause analysis - 5 Why's. Based on the research conducted, obtained waste results in the form of waiting and defects, with a value-added operating value of $11.54 \%, 7.69 \%$ non-value added, and necessary non-value-added operations of $76.43 \%$. Recommendations for improvement can reduce the total process activity from 26 to 24 and increase the value of PCE to $31.45 \%$.
\end{abstract}

Keywords: Lean Manufacturing; Root Cause Analysis; Value Stream Mapping; Waste 


\section{PENDAHULUAN}

PT XYZ merupakan salah satu perusahaan manufaktur yang bergerak dalam menyediakan kebutuhan home appliances, diantaranya adalah lemari es, mesin cuci, dan televisi. Berdasarkan hasil observasi awal dalam studi lapangan yang dilakukan di divisi Refrigerator PT XYZ, diperoleh permasalahan berupa pencapaian output produksi yang lebih rendah dibandingkan dengan target produksi pada Door PU produk kulkas 1 pintu serta freezer. Hal ini berdampak pada diberlakukannya kerja lembur (overtime) yang berdampak pada penambahan biaya tenaga kerja langsung bagi pekerja yang lembur. Beberapa penyebab dari perbedaan hasil output tersebut adalah banyaknya persentase produk cacat dan yang waktu menunggu cukup lama yang disebabkan oleh kerusakan mesin..

Pada hakikatnya, dalam proses produksi di suatu perusahaan pasti mempunyai waste (Khannan \& Haryono, 2015). Waste pada umumnya terdiri dari tujuh jenis yaitu overproduction (produksi berlebihan), waiting (menunggu), motion (pergerakan), transportation (transportasi), unnecessary process (proses yang tidak perlu), inventory (persediaan) dan defect (cacat) (Hines \& Rich, 1997). Pencapaian untuk meminimalkan pemborosan dapat dilakukan dengan melakukan pendekatan Lean manufacturing. Lean manufacturing merupakan konsep yang dapat mendesain proses produksi menjadi lebih baik, lebih cepat, dan lebih murah dengan ruang yang minim, inventory yang kecil, labour hour yang kecil, dan menghindari pemborosan (Womack \& Jones, 1997). Implementasi lean manufacturing dalam suatu perusahaan sendiri saat ini sudah banyak digunakan terutama pada perusahaan besar (Hines \& Rich, 1997; Sahoo, et,al, 2008).

Salah satu alat atau tools yang dapat digunakan untuk menerapkan lean adalah Value Stream Mapping (VSM). VSM merupakan metode yang menggambarkan seluruh proses yang ada pada suatu perusahaan (Rother \& Shook, 2003). Tujuan dari VSM adalah mengidentifikasi proses produksi agar material dan informasi dapat berjalan tanpa adanya gangguan, meningkatkan produktivitas dan daya saing, serta membantu dalam mengimplementasikan sistem (Womack \& Jones, 1997). Oleh karena itu VSM dapat membantu dalam menemukan waste atau permasalahan yang ada dalam proses produksi (Hartono, Prajadhiana, \& Nurhidayat, 2009; Seth, Seth, \& Goel, 2008)

Penggunaan lean manufacturing sudah diterapkan pada penelitian-penelitian terdahulu dalam proses optimalisasi proses produksi serta identifikasi waste atau pemborosan, seperti yang dilakukan pada proses identifikasi waste pada lini produksi Band Instrument Initial Process 2 Key Set Clarinet (Utama, Dewi, \& Mawarti, 2016). Dari penelitian tersebut penerapan konsep lean manufacturing berhasil mengidentifikasi waste yang ada yaitu defect, motion, inventory, dan waiting. Penelitian lain yang menerapkan konsep lean manufacturing adalah proses optimasi yang menghasilkan output berupa peningkatan hasil produksi dengan meminimasi waste yang ada pada proses produksi pada perusahaan manufaktur (Fernando \& Noya, 2014). Penerapan lean manufacturing juga digunakan dalam menganalisis pemborosan yang terjadi pada perusahaan mebel (Hartini, et, al., 2009). Lean manufacturing juga diterapkan dalam minimasi waiting time, seperti penelitian yang dilakukan pada proses produksi rubber step aspira (Kusuma, Suryadhini, \& Rahayu, 2016). Dari penerapan lean manufacturing menggunakan metode VSM juga digunakan untuk mencari rekomendasi perbaikan dari suatu proses produksi, dimana perbaikan ini dapat terlihat dari peningkatan nilai PCE proses (Ravizar \& Rosihin, 2018; Jasti \& Sharma, 2014; Seth et al., 2008).

Penelitian ini bertujuan mengetahui waste yang ada sebagai faktor penghambat produktivitas serta rekomendasi perbaikan untuk mengurangi waste tersebut. Hasil perbaikan ini diharapkan mampu meningkatkan produktivitas dan mengurangi waste yang terjadi.

\section{METODE PENELITIAN}

Data yang digunakan dalam penelitian ini diperoleh dari data primer serta sekunder. Data primer didapatkan melalui observasi secara langsung di lapangan, wawancara, serta diskusi bersama karyawan bagian produksi serta maintenance pada Divisi Door PU di PT XYZ. Sedangkan, data sekunder didapatkan dari dokumen-dokumen serta catatan perusahaan yang berhubungan dengan proses produksi serta sumber penelitian yang berkaitan sebagai penunjang penelitian ini.

Tahapan pertama yang dilakukan setelah proses pencarian data adalah penyusunan Value Stream Mapping (VSM). Value Stream Mapping berguna untuk melihat aliran proses fisik dan informasi material pada proses produksi (Yansen \& Bendatu, 2013). Selain itu, Value Stream Mapping juga dapat digunakan untuk mengetahui aliran informasi selama proses tersebut berlangsung (Hidayat, Tama \& Efranto, 2014). Data yang digunakan dalam proses penyusunan VSM ini adalah, data alur proses produksi, cycle time, data produk defect, dan data aliran informasi 
pada proses produksi yang berlangsung. Hasil dari VSM yang telah dibuat dapat diolah untuk mengidentifikasi waste yang ada pada proses produksi. Selanjutnya waste yang telah teridentifikasi dapat di breakdown kembali melalui penjabaran aktivitas yang terjadi pada process activity mapping. Dalam process activity mapping, dapat dilihat aktivitas yang memiliki nilai tambah dan juga aktivitas yang tidak memberi nilai tambah.

Tahap selanjutnya adalah proses identifikasi penyebab dari waste yang telah ditemukan. Proses identifikasi penyebab menggunakan tools root cause analysis dengan metode 5 Why's. Metode ini digunakan untuk mengetahui akar permasalahan dari waste yang ada.

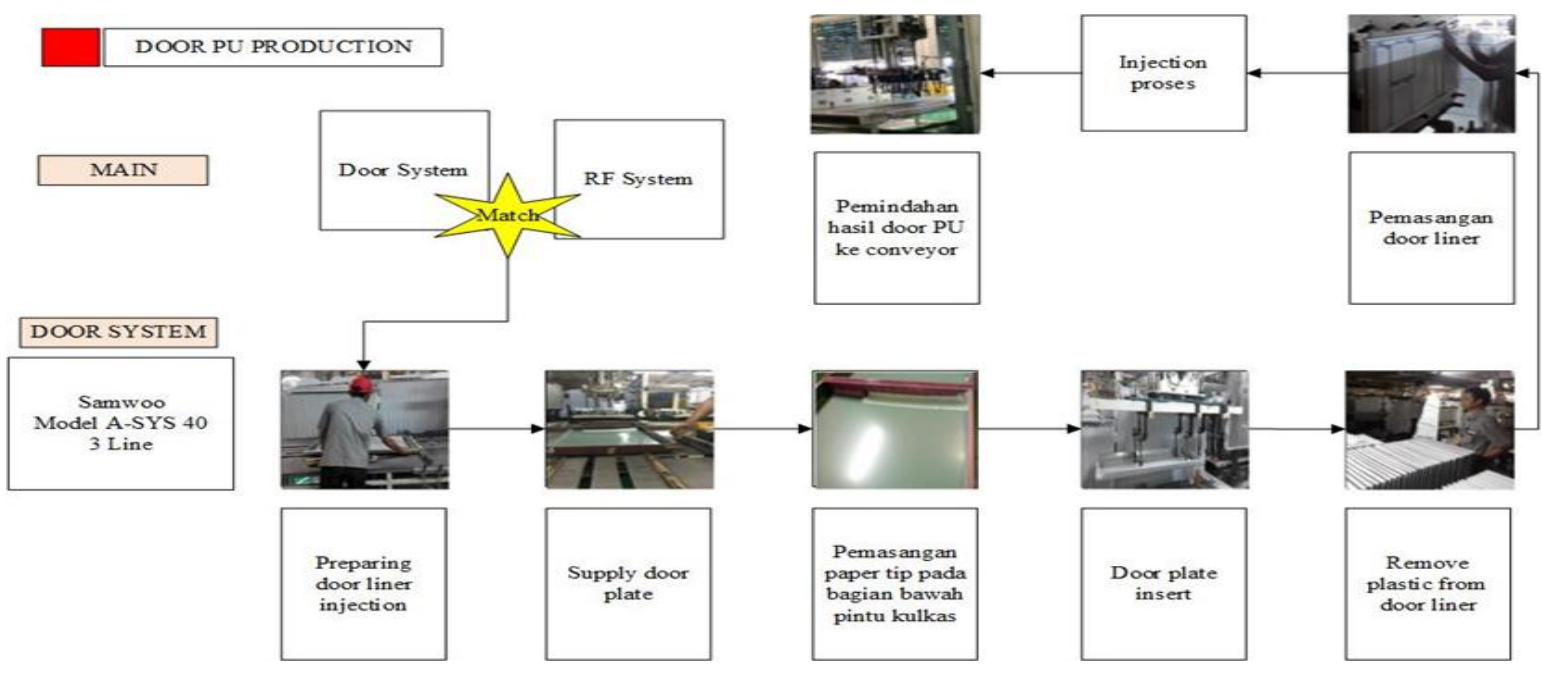

Gambar 1. Flow Process Door PU
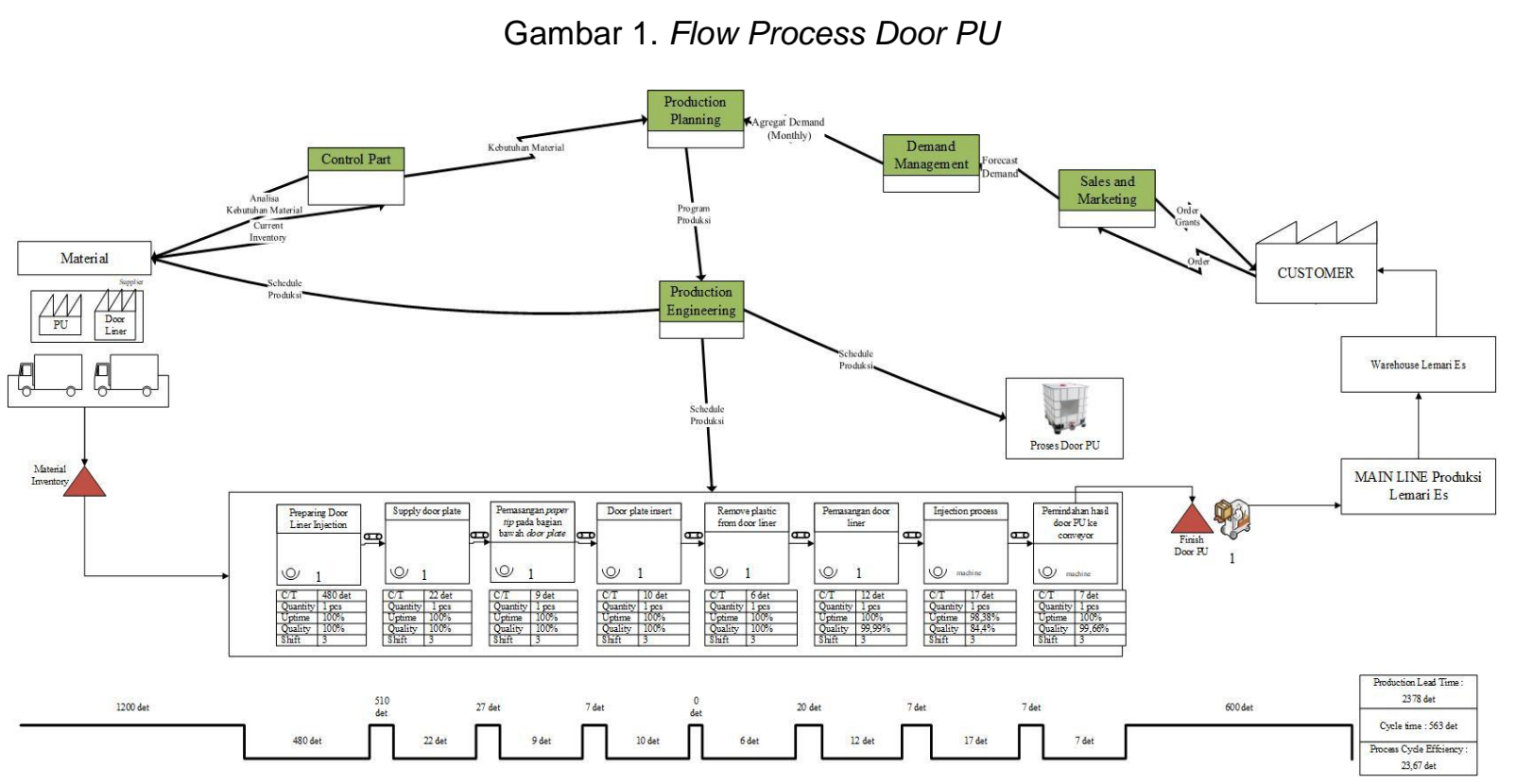

Gambar 2. Value Stream Mapping

\section{HASIL DAN PEMBAHASAN}

Proses Door PU terdiri dari beberapa tahapan, diantaranya adalah tahapan preparing door liner injection, supply door plate, pemasangan paper tip pada bagian bawah pintu kulkas, door plate insert, remove plastic from door liner, pemasangan door liner, dan injection process (Gambar 1).

Penyusunan Value Stream Mapping, membutuhkan data cycle time, data kualitas produk, data jumlah produksi, data downtime mesin, serta aliran proses. Data cycle time didapatkan dengan melakukan perhitungan menggunakan metode jam henti (stopwatch). Data yang diperoleh sebagai dasar pembuatan Current Value Stream Mapping (Gambar 2). 
Dari Value Stream Mapping yang telah dibuat, dapat diketahui bagaimana aliran informasi, aliran produk, aktivitas proses, serta waktu proses yang ada pada proses Door PU. Secara umum dari Value Stream yang ada terdapat masalah pada proses Door PU. Dimana salah satu aktivitas prosesnya yaitu proses injeksi memiliki nilai kualitas yang rendah sebesar $84,4 \%$ serta uptime mesin sebesar $98,38 \%$. Nilai PCE yang ada sebesar $23,67 \%$. Dari hasil tersebut menandakan terdapat 2 waste yang terdapat dari proses Door PU (Tabel 1).

Tabel 1. Identifikasi Waste

\begin{tabular}{llll}
\hline Waste & Skor & Rank & Persentase \\
\hline $\begin{array}{l}\text { Over production } \\
\text { Defect }\end{array}$ & 0 & 3 & $0 \%$ \\
$\begin{array}{l}\text { Stock on hand } \\
\text { inventory }\end{array}$ & 3 & 1 & $60 \%$ \\
$\begin{array}{l}\text { Inappropriate } \\
\text { processing }\end{array}$ & 0 & 3 & $0 \%$ \\
Transportation & 0 & 3 & $0 \%$ \\
Waiting & 0 & 3 & $0 \%$ \\
Movement & 2 & 2 & $40 \%$ \\
\hline
\end{tabular}

Hasil skor dari overproduction yaitu 0 yang artinya tidak terjadi produksi yang berlebihan dalam proses produksi. Hal ini dapat terjadi karena sistem yang dilakukan dalam proses pembuatan pintu ini adalah make-to-order dimana produk yang dibuat sesuai dengan jadwal produksi harian. Selanjutnya Hasil skor pada jenis waste unnecessary inventory yaitu 0 yang artinya masa simpan di dalam gudang tidak terlalu lama.

Hasil skor pada jenis waste excessive transportation yaitu 0 yang artinya total jarak yang ditempuh oleh produk selama proses pembuatan pintu sudah baik.

Hasil skor dari jenis waste defect yaitu 3 yang artinya defect terjadi rata-rata sebanyak 15 $20 \%$ dalam 1 bulan.

$$
\begin{aligned}
& \text { Defect rate }=\frac{\text { jumlah defect }}{\text { jumlah lemari es yang diproduksi }} \times 100 \% \\
& \text { Defect rate }=\frac{1651}{105.875} \times 100 \% \\
& \text { Defect rate }=15.6 \%
\end{aligned}
$$

Jenis waste defect merupakan waste terbanyak dengan bobot $60 \%$. Defect yang banyak terjadi yaitu di proses injeksi PU. Selain itu, hasil skor pada jenis waste waiting yaitu 2 yang artinya terjadi waktu menunggu selama 0,560 menit dalam satu kali proses produksi. Hal ini dapat terjadi dikarenakan beberapa proses yang berkaitan dengan penggunaan mesin.

\section{Proses Activity Mapping}

Process activity mapping diolah berdasarkan data yang terkumpul melalui observasi seluruh proses di lantai produksi dan pengambilan waktu langsung, aktivitas juga dilihat dan dibandingkan dengan Standard Operation Procedure (SOP) yang ada, tetapi juga mendokumentasikan aktivitas yang dilakukan diluar SOP sehingga dapat dilihat dengan jelas aktivitas yang berupa waste yang dilakukan oleh operator. Process activity mapping untuk proses produksi Door PU Line B dapat dilihat pada tabel

\begin{tabular}{|c|c|c|c|c|c|c|c|c|c|c|}
\hline \multirow{2}{*}{ No. } & \multirow{2}{*}{ Aktivitas } & \multirow{2}{*}{$\begin{array}{l}\text { Waktu } \\
\text { (detik) }\end{array}$} & \multicolumn{5}{|c|}{ Aktivitas } & \multicolumn{3}{|c|}{ Klasifikasi } \\
\hline & & & $\mathbf{O}$ & $\mathbf{T}$ & I & $\mathbf{S}$ & $\mathbf{D}$ & VA & NVA & NNVA \\
\hline 1 & $\begin{array}{l}\text { Menyiapkan cairan Poly Urethan (PU) yang akan } \\
\text { digunakan sebagai bahan injeksi }\end{array}$ & 600 & $\mathbf{X}$ & & & & & & & $\mathbf{x}$ \\
\hline 2 & $\begin{array}{l}\text { Proses pergantian } j i g \text { sesuai dengan model lemari } \\
\text { es yang akan dibuat serta pembersihan jig }\end{array}$ & 300 & $\mathbf{X}$ & & & & & & & $\mathbf{X}$ \\
\hline 3 & Mengatur jig & 180 & $\mathbf{X}$ & & & & & & & $\mathbf{X}$ \\
\hline 4 & $\begin{array}{l}\text { Mesin sementara berhenti operasi saat pergantian } \\
\text { jig }\end{array}$ & 480 & & & & & $\mathbf{x}$ & & $\mathbf{X}$ & \\
\hline 5 & $\begin{array}{l}\text { Mengatur keluaran bahan yang akan masuk ke } \\
\text { dalam jig }\end{array}$ & 30 & $\mathbf{X}$ & & & & & & & $\mathbf{X}$ \\
\hline 6 & Memindahkan door plate ke conveyor door $\mathrm{PU}$ & 5 & & $\mathbf{x}$ & & & & & & $\mathbf{x}$ \\
\hline 7 & Meletakkan door plate pada conveyor & 2 & $\mathbf{x}$ & & & & & & & $\mathbf{x}$ \\
\hline 8 & Conveyor bergerak & 7 & & $\mathbf{X}$ & & & & & & $\mathbf{X}$ \\
\hline 9 & Menunggu door plate sampai ke tempat injeksi PU & 10 & & & & & $\mathbf{X}$ & & & $\mathbf{X}$ \\
\hline 10 & Inspeksi terhadap door plate & 10 & & & $\mathbf{X}$ & & $\mathbf{X}$ & & $\mathbf{X}$ & \\
\hline
\end{tabular}
2.

Tabel 2. Process Activity Mapping 
Tabel 2. Process Activity Mapping (Lanjutan)

\begin{tabular}{|c|c|c|c|c|c|c|c|c|c|c|}
\hline \multirow{2}{*}{ No. } & \multirow{2}{*}{ Aktivitas } & \multirow{2}{*}{$\begin{array}{l}\text { Waktu } \\
\text { (detik) }\end{array}$} & \multicolumn{5}{|c|}{ Aktivitas } & \multicolumn{3}{|c|}{ Klasifikasi } \\
\hline & & & $\mathbf{O}$ & $\mathbf{T}$ & I & $\mathbf{S}$ & $\mathbf{D}$ & VA & NVA & NNVA \\
\hline 11 & Mengambil masking tape & 2 & & & & & $\mathbf{x}$ & & & $\mathbf{X}$ \\
\hline 12 & $\begin{array}{l}\text { Memasang masking tape pada bagian bawah door } \\
\text { plate }\end{array}$ & 7 & $\mathbf{x}$ & & & & & & & $\mathbf{x}$ \\
\hline 13 & $\begin{array}{l}\text { Membawa door plate dari conveyor ke arah } \\
\text { vacuum }\end{array}$ & 7 & & $\mathbf{x}$ & & & & & & $\mathbf{x}$ \\
\hline 14 & Vacuum mengambil door plate ke jig & 7 & & $\mathbf{X}$ & & & & & & $\mathbf{X}$ \\
\hline 15 & Memasang door plate pada jig & 3 & $\mathbf{x}$ & & & & & $\mathbf{x}$ & & \\
\hline 16 & Membuka kemasan plastik door liner dari supplier & 6 & $\mathbf{x}$ & & & & & & & $\mathbf{x}$ \\
\hline 17 & $\begin{array}{l}\text { Membawa door liner yang sudah dilepas } \\
\text { plastiknya ke bagian atas proses injeksi PU }\end{array}$ & 15 & & $\mathbf{X}$ & & & & & & $\mathbf{x}$ \\
\hline 18 & Menunggu jig bergerak untuk pergantian model & 5 & & & & & $\mathbf{x}$ & & $\mathbf{x}$ & \\
\hline 19 & $\begin{array}{l}\text { Memasang door liner pada jig sesuai dengan } \\
\text { model pintu yang akan diproses }\end{array}$ & 12 & $\mathbf{x}$ & & & & & $\mathbf{x}$ & & \\
\hline 20 & Jig bergerak untuk proses injeksi PU & 7 & & & & & $\mathbf{x}$ & & & $\mathbf{x}$ \\
\hline 21 & Proses injeksi PU di dalam mesin & 17 & $\mathbf{X}$ & & & & & $\mathbf{x}$ & & \\
\hline 22 & Jig terbuka saat proses injeksi telah selesai & 4 & & & & & $\mathbf{x}$ & & & $\mathbf{x}$ \\
\hline 23 & $\begin{array}{l}\text { Mengangkat door yang sudah selesai di injeksi } \\
\text { dengan menggunakan vacuum }\end{array}$ & 3 & $\mathbf{x}$ & & & & & & & $\mathbf{x}$ \\
\hline 24 & Memindahkan door ke conveyor & 5 & & $\mathbf{x}$ & & & & & & $\mathbf{x}$ \\
\hline 25 & Meletakkan door pada conveyor & 2 & $\mathbf{X}$ & & & & & & & $\mathbf{x}$ \\
\hline 26 & Inspeksi & 10 & & & $\mathbf{x}$ & & & & & $\mathbf{x}$ \\
\hline
\end{tabular}

Berdasarkan tabel 2 diperoleh total jumlah keseluruhan aktivitas yaitu 27 aktivitas, terdapat 3 aktivitas bernilai tambah (VA) yaitu aktivitas operation dengan prosentase $11,54 \%$, lalu terdapat 2 aktivitas yang tidak bernilai tambah (NVA) yaitu aktivitas delay dengan prosentase $7,69 \%$, kemudian aktivitas yang tidak bernilai tambah tetapi diperlukan (NNVA) terdapat 21 aktivitas termasuk aktivitas operate, transport, dan inspeksi dengan presentase 76,43\% (Tabel 3).

Tabel 3. Rekapitulasi Activity Mapping

\begin{tabular}{ccccc}
\hline Aktivitas & Jumlah & $\begin{array}{c}\text { Prosent } \\
\text { ase }\end{array}$ & $\begin{array}{c}\text { Waktu } \\
\text { (detik) }\end{array}$ & $\begin{array}{c}\text { Prosent } \\
\text { ase }\end{array}$ \\
\hline VA & 3 & $11.54 \%$ & 42 & $1.88 \%$ \\
NVA & 2 & $7.69 \%$ & 485 & $21.69 \%$ \\
NNVA & 21 & $80,77 \%$ & 1709 & $76.43 \%$ \\
Total & 26 & $100.00 \%$ & 2236 & $100.00 \%$ \\
\hline
\end{tabular}

Pada aktivitas NVA terdapat proses waiting, berupa menunggu pergantian jig serta downtime mesin. Selain itu terdapat juga aktivitas terkait kualitas produk berupa inspeksi. Hasil ini mendukung hasil identifikasi awal mengenai waste yang ada yaitu berupa waiting dan defect. Nilai PCE dari kondisi awal proses produksi yang berlangsung adalah sebesar $23,67 \%$

\section{Root Cause Analysis - 5Why's}

Root cause analysis ini digunakan untuk mencari penyebab dari waste yang berlangsung pada proses Door PU. Sedangkan metode 5 Why's dipilih karena dengan menggunakan metode ini dapat diketahui akar permasalahan dari waste yang ada. Root cause analysis dapat dilihat dalam tabel 4 dengan waste berupa defect dan waiting. Defect yang terjadi antara lain Pintu penyok sebanyak 362 buah, Door liner keriput sebanyak 160 buah, Door liner ambles sebanyak 842 buah dan Door liner ambles sebanyak 842 buah. Adapun waiting yang terjadi adalah menunggu jalur, pergantian jig, dan downtime mesin. 
Tabel 4. Root Cause Analysis 5-Why's

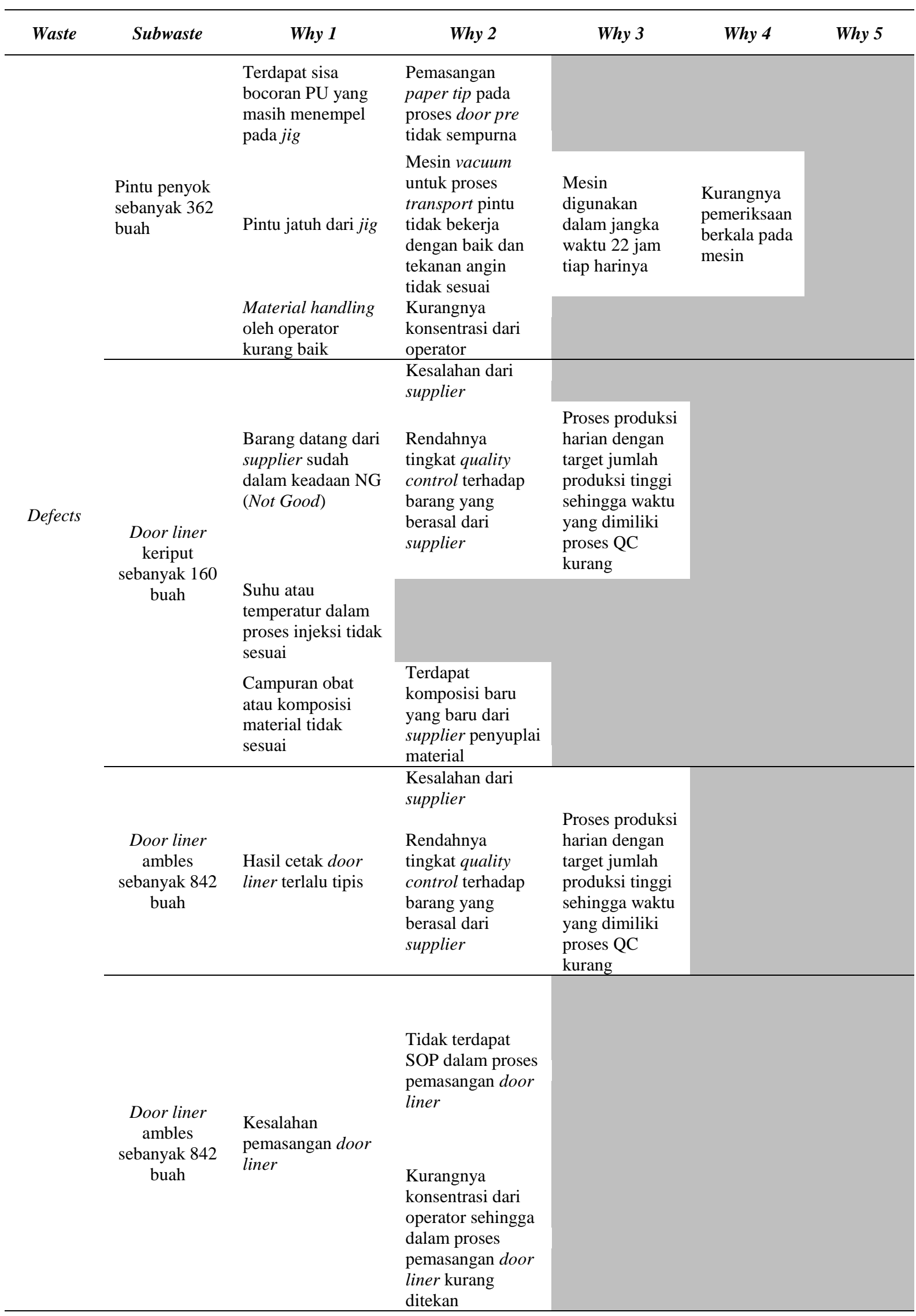


Tabel 4. Root Cause Analysis 5-Why's (Lanjutan)

\begin{tabular}{|c|c|c|c|c|c|c|}
\hline Waste & Subwaste & Why 1 & Why 2 & Why 3 & Why 4 & Why 5 \\
\hline \multirow{4}{*}{ Waiting } & \multirow[b]{2}{*}{ Tunggu jalur } & $\begin{array}{l}\text { Proses pemanasan } \\
\text { jig untuk } \\
\text { menghasilkan hasil } \\
\text { cetak injeksi yang } \\
\text { baik }\end{array}$ & & & & \\
\hline & & $\begin{array}{l}\text { Terdapat jig yang } \\
\text { bermasalah atau } \\
\text { error }\end{array}$ & $\begin{array}{l}\text { Masih terdapat sisa } \\
\text { bocoran PU pada jig } \\
\text { sehingga membuat } \\
\text { pintu sebelumnya } \\
\text { penyok, dimana jig } \\
\text { tersebut harus } \\
\text { dibersihkan terlebih } \\
\text { dahulu }\end{array}$ & & & \\
\hline & Pergantian jig & $\begin{array}{l}\text { Pergantian model } \\
\text { pintu yang akan } \\
\text { dibuat sehingga } \\
\text { mengharuskan } \\
\text { adanya pergantian } \\
\text { jig }\end{array}$ & $\begin{array}{l}\text { Jumlah model pintu } \\
\text { yang dibuat setiap } \\
\text { harinya banyak serta } \\
\text { sistem pergantian per } \\
\text { modelnya tidak } \\
\text { berurutan }\end{array}$ & & & \\
\hline & $\begin{array}{l}\text { Downtime } \\
\text { mesin }\end{array}$ & $\begin{array}{l}\text { Terjadi error pada } \\
\text { bagian mixing head }\end{array}$ & & & & \\
\hline
\end{tabular}

\section{Rekomendasi Perbaikan}

Untuk mempercepat proses produksi, dapat dilakukan perawatan mesin secara berkala untuk mengurangi waktu downtime (waiting) yang berpengaruh pada lamanya waktu proses. Waktu yang dibutuhkan dalam melakukan perbaikan sendiri mencapai 10 menit di setiap harinya. Pekerjaan inspeksi dapat dilakukan berupa Condition-Directed Task yaitu mendeteksi kerusakan dengan cara memeriksa alat. Mengamati, dan mendeteksi kelainan-kelainan yang terjadi pada mesin Door $P U$ line $B$. Kemudian melakukan pemeriksaan Time-Directed Life-Renewal Task yaitu mengganti ataupun memperbaiki sebuah peralatan sebelum peralatan rusak dalam mesin Door PU line B seperti vacuum yang dipasang pada unloader.

Rekomendasi perbaikan yang dapat mempercepat proses cycle time dan mengurangi defect berupa door liner ambles adalah dengan membuat lembar kerja list model yang akan diproduksi mengingat banyaknya model yang ada. Dengan ini operator tidak membuang waktu lama untuk proses pemasangan door liner pada jig. Perbaikan lain dilakukan dengan menghilangkan proses peletakan door plate dari conveyor yang dilakukan secara manual. Dimana proses ini dapat dilakukan langsung dengan conveyor yang terhubung dengan mesin vacuum dan untuk meminimalisir adanya kesalahan material handling dari operator yang dapat menyebabkan pintu penyok.

Dari hasil perbaikan ini didapatkan Future Process Activity Mapping didapatkan perubahan jumlah total aktivitas dari 26 aktivitas menjadi 24 aktivitas (Tabel 5). Dari Value Stream Mapping sebelum perbaikan, didapatkan nilai PCE yang cukup rendah, yaitu sebesar $23,67 \%$. Rendahnya nilai tersebut disebabkan oleh lamanya total lead time yang dibutuhkan. Nilai ini berada di bawah kriteria penerapan lean manufacturing, dimana perusahaan dikatakan lean apabila memiliki nilai PCE minimal $30 \%$. Setelah dilakukan identifikasi waste, didapatkan dua waste yang terjadi dalam proses yaitu defect dan waiting. Waste berupa defect dibuktikan dengan nilai defect rate yang tinggi sebesar $15,6 \%$ dan waste waiting dibuktikan dengan jumlah waktu aktivitas NVA berupa delay sebesar $21.89 \%$ dari waktu produksi.

Hasil root analysis menunjukkan bahwa penyebab terjadinya waste adalah dikarenakan kurangnya pemeriksaan berkala pada mesin, dimana hal itu menyebabkan mesin tidak dapat bekerja dengan baik dan menghasilkan output berupa produk yang cacat serta mengharuskan adanya proses perbaikan mesin yang mengganggu jadwal produksi. Penyebab umum lainnya adalah masih adanya proses manual oleh 
operator, yang menyebabkan tingkat kesalahan proses menjadi lebih tinggi. Dari hasil ini, maka diberikan rekomendasi perbaikan berupa perawatan mesin secara berkala dan menghilangkan proses peletakan door plate dari conveyor yang dilakukan secara manual untuk diganti secara otomatis melalui vacuum.

Hasil dari penerapan rekomendasi perbaikan digambarkan melalui Future Value Stream Mapping. Nilai PCE pada Future Value Stream Mapping menunjukkan peningkatan menjadi $31,45 \%$. Hal ini berarti proses perbaikan yang dipilih berhasil meningkatkan efisiensi proses produksi, dimana semakin besar nilai PCE maka proses berjalan lebih efisien.

Tabel 2. Future Process Activity Mapping

\begin{tabular}{|c|c|c|c|c|c|c|c|c|c|}
\hline \multirow[t]{2}{*}{ No. } & \multirow{2}{*}{ Aktivitas } & \multirow{2}{*}{$\begin{array}{l}\text { Waktu } \\
\text { (detik) }\end{array}$} & \multicolumn{4}{|c|}{ Aktivitas } & \multicolumn{3}{|c|}{ Klasifikasi } \\
\hline & & & $\mathbf{O}$ & $\mathbf{T}$ & $\mathbf{I} \mathbf{S}$ & D & VA & NVA & NNVA \\
\hline 1 & $\begin{array}{l}\text { Menyiapkan cairan Poly Urethan (PU) yang akan } \\
\text { digunakan sebagai bahan injeksi }\end{array}$ & 600 & $\mathbf{x}$ & & & & & & $\mathbf{X}$ \\
\hline 2 & $\begin{array}{l}\text { Proses pergantian } j i g \text { sesuai dengan model lemari es } \\
\text { yang akan dibuat }\end{array}$ & 300 & $\mathbf{X}$ & & & & & & $\mathbf{x}$ \\
\hline 3 & Mengatur jig & 180 & $\mathbf{X}$ & & & & & & $\mathbf{X}$ \\
\hline 4 & Mesin sementara berhenti operasi saat pergantian jig & 480 & & & & $\mathbf{X}$ & & $\mathbf{X}$ & \\
\hline 5 & $\begin{array}{l}\text { Mengatur keluaran bahan yang akan masuk ke dalam } \\
\text { jig }\end{array}$ & 30 & $\mathbf{X}$ & & & & & & $\mathbf{x}$ \\
\hline 6 & Memindahkan door plate ke conveyor door $\mathrm{PU}$ & 5 & & $\mathbf{X}$ & & & & & $\mathbf{x}$ \\
\hline 7 & Meletakkan door plate pada conveyor & 2 & $\mathbf{x}$ & & & & & & $\mathbf{x}$ \\
\hline 8 & Conveyor bergerak & 7 & & $\mathbf{X}$ & & & & & $\mathbf{x}$ \\
\hline 9 & Menunggu door plate sampai ke tempat injeksi PU & 10 & & & & $\mathbf{x}$ & & & $\mathbf{x}$ \\
\hline 10 & Inspeksi terhadap door plate & 10 & & & $\mathbf{X}$ & $\mathbf{X}$ & & & $\mathbf{x}$ \\
\hline 11 & Mengambil masking tape & 2 & & & & $\mathbf{X}$ & & & $\mathbf{X}$ \\
\hline 12 & $\begin{array}{l}\text { Memasang masking tape pada bagian bawah door } \\
\text { plate }\end{array}$ & 7 & $\mathbf{X}$ & & & & & & $\mathbf{x}$ \\
\hline 13 & Vacuum mengambil door plate ke jig & 7 & & $\mathbf{X}$ & & & & & $\mathbf{x}$ \\
\hline 14 & Memasang door plate pada jig & 3 & $\mathbf{x}$ & & & & $\mathbf{x}$ & & \\
\hline 15 & Membuka kemasan plastik door liner dari supplier & 6 & $\mathbf{X}$ & & & & & & $\mathbf{X}$ \\
\hline 16 & $\begin{array}{l}\text { Membawa door liner yang sudah dilepas plastiknya } \\
\text { ke bagian atas proses injeksi PU }\end{array}$ & 15 & & $\mathbf{x}$ & & & & & $\mathbf{X}$ \\
\hline 17 & Menunggu jig bergerak untuk pergantian model & 5 & & & & $\mathbf{X}$ & & $\mathbf{X}$ & \\
\hline 18 & $\begin{array}{l}\text { Memasang door liner pada jig sesuai dengan model } \\
\text { pintu yang akan diproses }\end{array}$ & 8 & $\mathbf{X}$ & & & & $\mathbf{x}$ & & \\
\hline 19 & Jig bergerak untuk proses injeksi PU & 7 & & & & $\mathbf{X}$ & & & $\mathbf{X}$ \\
\hline 20 & Proses injeksi PU di dalam mesin & 17 & $\mathbf{X}$ & & & & $\mathbf{x}$ & & \\
\hline 21 & Jig terbuka saat proses injeksi telah selesai & 4 & & & & $\mathbf{X}$ & & & $\mathbf{x}$ \\
\hline 22 & $\begin{array}{l}\text { Mengangkat door yang sudah selesai di injeksi } \\
\text { dengan menggunakan vacuum }\end{array}$ & 3 & $\mathbf{X}$ & & & & & & $\mathbf{X}$ \\
\hline 23 & Memindahkan door ke conveyor & 5 & & $\mathbf{X}$ & & & & & $\mathbf{X}$ \\
\hline 24 & Inspeksi & 10 & & & $\mathbf{X}$ & & & & $\mathbf{X}$ \\
\hline
\end{tabular}




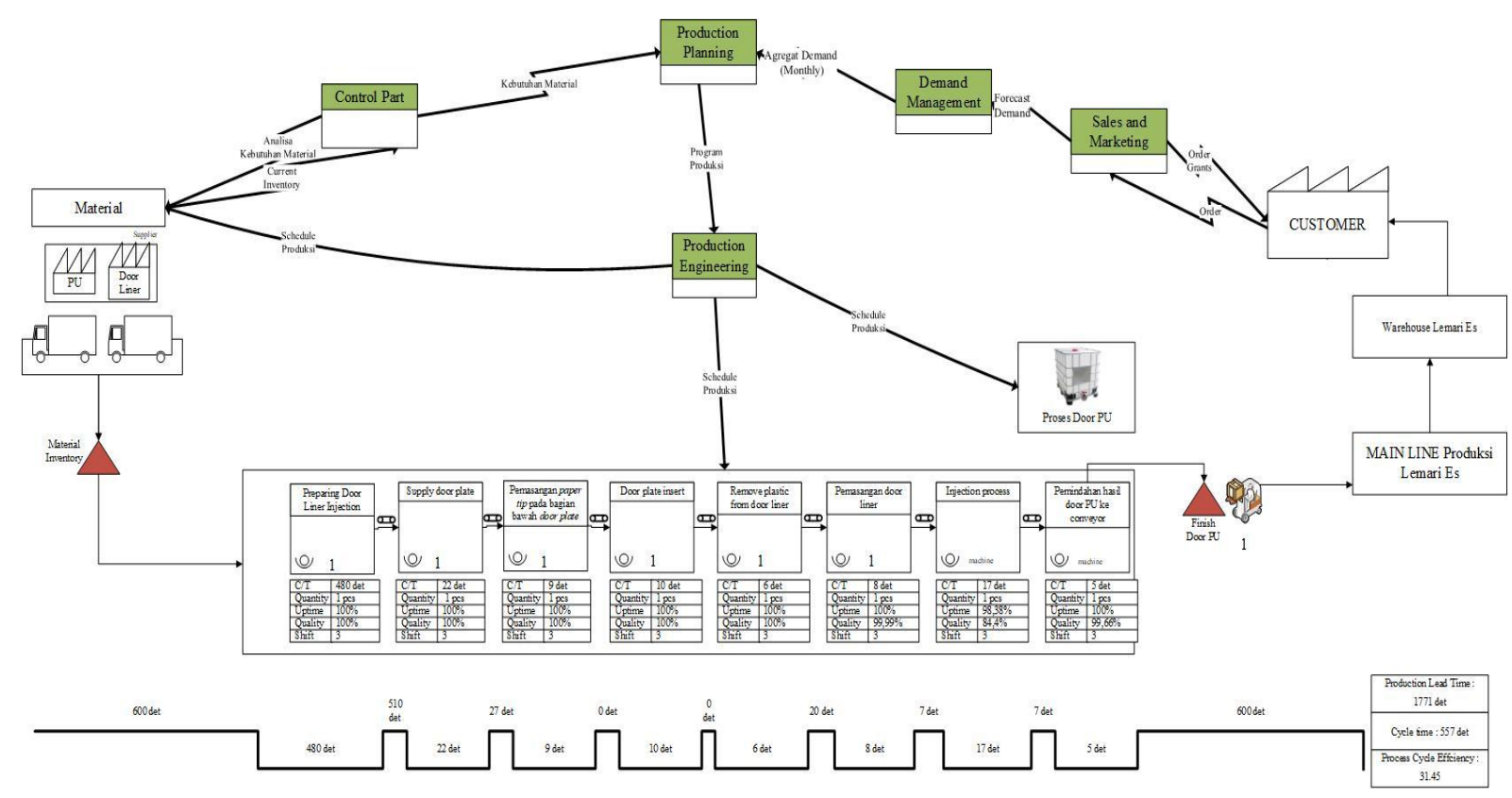

Gambar 3. Future Value Stream Mapping

\section{KESIMPULAN}

Berdasarkan pengolahan data dan analisis diketahui terdapat dua waste yang ditemukan pada proses produksi Door PU line B yaitu waste berupa defect dan waiting. Perbaikan proses sesuai dengan root analysis mampu merampingkan proses Door PU line B dari 26 aktivitas menjadi 24 aktivitas. Perubahan jumlah aktivitas mampu meningkatkan nilai PCE dari $23,67 \%$ menjadi $31,45 \%$. Penelitian lanjutan yang dapat dilakukan adalah melakukan penelitian mengenai manajemen produksi yang dapat dikaji untuk meningkatkan efisiensi proses produksi, terutama dengan adanya penerapan produksi multi item yang berlangsung.

\section{DAFTAR PUSTAKA}

Fernando, Y. C., \& Noya, S. (2014). Optimasi lini produksi dengan value stream mapping dan value stream analysis tools. Jurnal IImiah Teknik Industri, 13(2), 125-133. Retrieved from

http://journals.ums.ac.id/index.php/jiti/article /view/630

Hartini, S., Saptadi, S., Kadarina, N., \& Rizkya, I. (2009). Analisis Pemborosan Perusahaan Mebel Dengan Pendekatan Lean Manufacturing (Studi Kasus PT " $X$ " Indonesia). J@ TI UNDIP, 4(2), 95-105. Retrieved from https://ejournal.undip.ac.id/index.php/jgti/arti cle/view/1941

Hartono, G., Prajadhiana, D., \& Nurhidayat, S.
(2009). Implementing Value Stream Mapping (VSM) On Production Process of Blank Cylinder head at PT X. Industrial and Systems Engineering Assessment Journal (INASEA), 10(1), 1-7. Retrieved from http://202.58.182.161/index.php/inasea/artic le/view/97

Hidayat, R., Tama, I. P., \& Efranto, R. Y. (2014). Penerapan Lean Manufacturing Dengan Metode VSM Dan FMEA Untuk Mengurangi Waste Pada Produk Plywood (Studi Kasus Dept. Produksi Pt Kutai Timber Indonesia). Jurnal Rekayasa dan Manajemen Sistem Industri, 2(5), 10321043. Retrieved from http://jrmsi.studentjournal.ub.ac.id/index.php /jrmsi/article/view/148.

Hines, P., \& Rich, N. (1997). The seven value stream mapping tools. International Journal of Operations \& Production Management, 17(1), $\quad$ 46-64. https://doi.org/10.1108/0144357971015798 9

Jasti, N. V. K., \& Sharma, A. (2014). Lean manufacturing implementation using value stream mapping as a tool. International Journal of Lean Six Sigma, 5(1), 89-116. https://doi.org/10.1108//JLSS-04-2012-0002

Khannan, M. S. A., \& Haryono, H. (2015). Analisis Penerapan Lean Manufacturing untuk Menghilangkan Pemborosan di Lini Produksi PT Adi Satria Abadi. Jurnal Rekayasa Sistem Industri, 4(1), 47-54. 
https://doi.org/10.26593/jrsi.v4i1.1383.47-54

Kusuma, Q., Suryadhini, P. P., \& Rahayu, M. (2016). Rancangan Usulan Perbaikan untuk Meminimasi Waiting TIME pada Proses Produksi Rubber Step Aspira Belakang dengan Pendekatan Lean Manufacturing (Studi Kasus: PT Agronesia Divisi Industri Teknik Karet). Jurnal Rekayasa Sistem \& Industri (JRSI), 3(02), 52-61. https://doi.org/https://doi.org/10.25124/jrsi.v 3i02.32.

Ravizar, A., \& Rosihin, R. (2018). Penerapan Lean Manufacturing untuk Mengurangi Waste pada Produksi Absorbent. Jurnal INTECH Teknik Industri Universitas Serang Raya, 4(1), 23-32. https://doi.org/10.30656/intech.v4i1.854.

Rother, M., \& Shook, J. (2003). Learning to see: value stream mapping to add value and eliminate muda. Lean Enterprise Institute. Retrieved from Googe Scholar.

Sahoo, A. K., Singh, N. K., Shankar, R., \& Tiwari, M. K. (2008). Lean philosophy: implementation in a forging company. The International Journal of Advanced Manufacturing Technology, 36(5-6), 451462. https://doi.org/10.1007/s00170-0060870-2

Seth, D., Seth, N., \& Goel, D. (2008). Application of value stream mapping (VSM) for minimization of wastes in the processing side of supply chain of cottonseed oil industry in Indian context. Journal of Manufacturing Technology Management, 19(4), 529-550. https://doi.org/10.1108/1741038081086995 0

Utama, D. M., Dewi, S. K., \& Mawarti, V. I. (2016). Identifikasi Waste Pada Proses Produksi Key Set Clarinet Dengan Pendekatan Lean Manufacturing. Jurnal IImiah Teknik Industri, 15(1), 36-46. https://doi.org/10.23917/jiti.v15i1.1572

Womack, J. P., \& Jones, D. T. (1997). Lean Thinking-Banish Waste and Create Wealth in your Corporation. In Journal of the Operational Research Society (Vol. 48, pp. 1148-1148). Taylor \& Francis. https://doi.org/10.1057/palgrave.jors.260096 7

Yansen, O., \& Bendatu, L. Y. (2013). Perancangan Value Stream Mapping dan Upaya Penurunan Lead time pada Bagian Procurement-Purchasing di PT X. Jurnal Titra, 1(2), 9-16. Retrieved from http://publication.petra.ac.id/index.php/tekni k-industri/article/view/966 